\title{
State of Wetland Transformation and Ecological Concerns - A Case Study of Chatra Wetland, English Bazr, West Bengal
}

\author{
Dr. Shyamal Kumar Kar* \\ Assistant Teacher, Nayansukh L.N.S.M High School, Jafarganj, Murshidabad, West Bengal, India
}

*Corresponding Author: Dr. Shyamal Kumar Kar, Assistant Teacher, Nayansukh L.N.S.M High School, Jafarganj, Murshidabad, West Bengal, India Email: shyamalkarjha@gmail.com

\begin{abstract}
Chatra Beel, one of the largest wetland with more than 100 ha water cover area, is located at the south western outskirts of English Bazar town of Malda District, West Bengal. It acts as the kidney of English bazar urban area with its multifarious usabilities both from ecological and economic perspectives. Till 1970 Chatra Wetland was not a wetland, people own the land for agricultural purpose, orchard, mango garden etc. In the post Farakka barrage period (1974 on ward) due to construction of afflux embankment, NH34, embankment and railway line embankment natural drainage line have severely being obstructed leading to creation of this wetland. So, this is not a natural wetland. But for the last three (3) decades or more this area remained as a wetland and the physico-hydrological and ecological characteristics, have been generated as part of natural processes. Now after years of retention of wetland characteristics the area is now undergoing reclamation process for human occupation, essentially built up area, as spill over of English Bazar urban area. This definitely puts a question up from ecological perspective but at the same time there are strong reasons and explanations in support of this conversion since originally this region was not a wetland at all. Owing to the impact, the entire situation places a very interesting case. Therefore it will be attempted through this work to identify the nature and degree of consequences of human intervention leading to resultant effects on the natural ecological system of Chatra wetland.
\end{abstract}

Keywords: Wetland (Beel), Economic Prospects, Perspective Planning, Synchronization of ecology and economy.

\section{INTRODUCTION}

Every wetland possesses certain commonalities as well as uniqueness on its own. Wetlands play an integral role in the ecology and hydrology of an area; on the other hand, wetlands can have social or economic values too. Wetlands are capable of providing many additional services and benefits provided by wetlands that are often less tangible. Water quality improvement, flood protection can all be supported by wetlands depending on their type and location. Wetlands are nature's water purifiers. Wetlands have important filtering capabilities for intercepting surface water runoff. That is why Wetlands are often described as biological supermarkets" and "kidneys of the landscape" (Mitsch \& Gosselink 1993) (11). Wetlands are of inestimable value for the supply of goods and services to society (; Mitsch and Gosselink, 2000) (9), yet they are threatened globally (Maltby, 1991; Ramsar Convention Bureau, 1997) (12). Ahamed, S.I., Tiwana, A.S. (2005) (1) in their article Disappearing Wetlands: A Threats to Biodiversity published in Geographical Review of India argued that wetland is geo environmentally precious but our indifference over looking and desperate tapping for profit making wetland areas have been gradually devastatingly losing their existence.

In ecological concerns a wetland is an integral part of the ecosystem in a region. The entire regional physical set-up is intertwined with that of the properties of the wetland. Any exogenetic change injected in the wetland will not only endanger the wetland itself but will also inflict deadly physicoenvironmental consequences in the long run. In such case the very existence of regional ecosystem which also includes human existence will be under severe threat.

On the other, Wetlands belong to flat plain topography thereby its prospects of other human uses (non-aquatic in nature) may be of several folds. Urban proximity reduces conservation possibilities of wetlands. Pressing demand for built-up areas are enhanced naturally. By virtue of urban proximity the price of land becomes high. The attraction is difficult to ignore by the land owners in the proximity of 
wetlands. The permanent water bodies (a wetland) usually do not call for conservation initially and littoral areas are obvious choices. When this area is filled up (by built up units) intrusion in the water body through land fill becomes obvious too. Ever-increasing unit price of land in urban areas and moreover, the gradual non availability of physical space within the urban limit the growing urban population has to spill over outwards. The very vacant character of wetland area therefore, may become, if not compulsively an obvious choice.

Chatra wetland has its multifarious usabilities both from ecological and economic point of view. Chatra wetland is called as the 'lung' of Malda town and performs some useful functions in the maintenance of overall balance of nature of this district (Chattaraj \& Chattaraj, 2008) (3). But the wetland is now under the threats of extinction. Within last 15 years, wetland scenario has changed a lot. More than $50 \%$ of this has been captured by urban settlement (Kar, S.K., and Pal, S. 2012) (4). So, questions may be raised about the ongoing process of conversion of it through urban encroachment.

\section{STUDY AREA}

English bazaar town is the district head quarter and only municipal town of Malda district in West Bengal. Chatra wetland, one of the vast artificial wetland, is located at the south western outskirts of Malda town. Administratively this wetland is under the ward no. 3 and 25 of English Bazar Municipality and also partly of Pirojpur Mouza (J.L No. 69); Arazi Dilalpur (J.L. No. 70); Abhirampur (J.L. No. 91); Gabgachi (J.L. No. 90) \& Uttar Jadupur (J.L. No. 88) of English Bazar Block. The beel is situated at an altitude of 29 meters above mean sea level. A survey was conducted by the 'Director of Fisheries Office' Malda District (2009) the beel area is approximate 142 hectares in monsoon months and is restricted to 65.00 hectares only in pre-monsoon period. But the water spreaded area of this unique wetland is changed during heavy rains year. There is no directly drainage linkage with any river system to this beel. The wetland was connected with two small drains which are located along the longitude $2459^{\prime} 50$ 'N \& 88 8'E and $2500^{\prime} 18^{\prime \prime} \mathrm{N} \& 88$ 07' 34'"E in ward no.3 of the English Bazar municipality. Intrusion of municipal waste water through these two drains \& also surface discharge water are permanent source of water intake of this wetland.

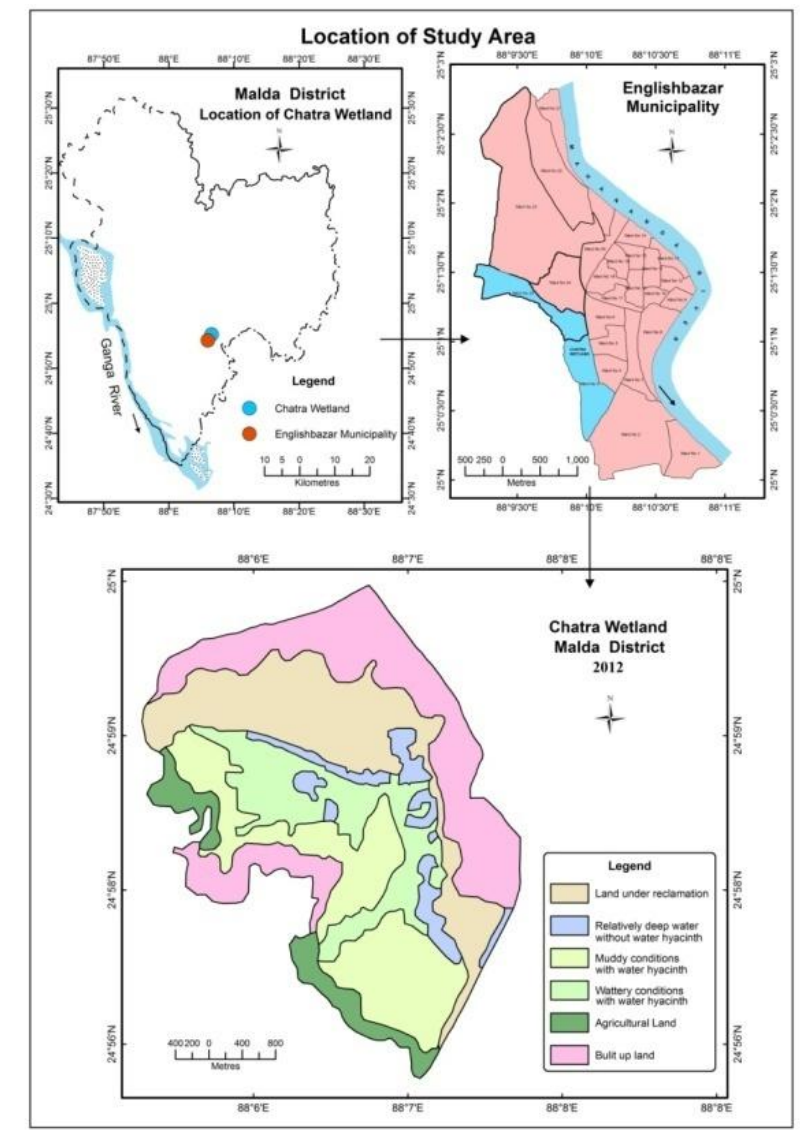

Fig1 


\section{OBJECTIVES}

The major objective is to explore the state of wetland transformation and associated ecological concerns. It is also tried to focus whether this transformation is ecologically justified.

\section{MATERIALS AND Methods}

Most of the primary data have been collected through empirical field survey, perception studies of the wetland dwellers and environment concerned people. On the other hand, secondary data related to wetland pattern and distribution, spatial data about time series change of Chatra wetland area, were obtained from Cadastral map of different mouzas 1931, Toposheet of the Survey of India 1968-69 and satellite imageries, 2010 from net (www.wikimapia.com). The Methodology for the entire work has been kept as simple and transparent as possible, both statistically and cartographically. Coefficient of determination $\left(\mathrm{R}^{2}\right)$ has been used to show the trend of ground water condition of English Bazar town.

\section{RESUlTS AND ANALYSIS}

\subsection{Genesis of Chatra Wetland}

As per record of Survey by Settlement Officer and Superintendent of Survey made in 1930-31, most of the present wetland area was under agricultural low land and north eastern portion was under mango orchard. Major portion of that particular area was mainly used as only for paddy cultivation purpose during monsoon period. But this low land track had played a very significant role for allowing flood water to pass through and also excessive rain water to Bhatia Beel and protected the town English Bazar and adjacent area. So far as its genesis is concerned, this wetland was come up in 1971 when raised railway line embankment, without adequate through water passage system, was constructed. Its catchment area is not totally closed because from western part one drainage channel is entering into the wetland carrying sizeable quantity of water from surrounding regions. But its outlet point is very narrow and quite elevated from the normal bed level of the wetland. Moreover, the extended outlet course which joins this wetland with River Mahananda, has also critically undergone into massive fragmentation and transformation. This condition is also resisting the general flow pattern of this wetland. Thus in general there is very little scope to total draining out of the existing water of the wetland. During 1998 almost the entire Rarh and Barind region of West Bengal was seriously affected by torrential rain and consequent flood. As a result huge amount of water got stagnated within the wetland. It caused spatial extension of the wetland area and rise of average water level on the wetland. But now, Irrigation department has planned to make a new course connecting Chatra wetland and Mahananda River to drain out the wetland and reclaim the entire land for habitation and other economic usages.

\subsection{Wetland Transformation}

There is no other suitable town other than Malda in Malda district therefore pressure of floating population is very high in this town. In this condition demand for land is sky rocketing. There is no suitable provision of urban growth in the eastern side of the existing town due to River Mahananda. Similarly, people are more attracted to stay nearer to the market, railway station etc naturally. So, the growth of the town is not very remarkable in the southern portion. Given this situation wetland conversion process has got enough momentum.

The fact is that people have lost their agricultural land but when they get it back, they are ready to sell it to the promoters or those people who individually are willing to buy them for built up purpose. The interim event of wetland formation between previous agricultural land and built up land, the valuation of land is multiplied several times. Owing to the impact, owner of land of Chatra wetland is highly inclined to convert the wetland into built up land. Promoters are fueling their idea vigorously for obvious reasons. As a result, people have built their houses in the reclaimed part of the beel since 2002 with clear administrative documents and approval. Present rate of wetland piracy indicates its short longevity. Finally, it can be said that there is that comprehending all these problems, short term money oriented profit making mind set of the people is the most dangerous threat for Chatra wetland. 
State of Wetland Transformation and Ecological Concerns - A Case Study of Chatra Wetland, English Bazr, West Bengal

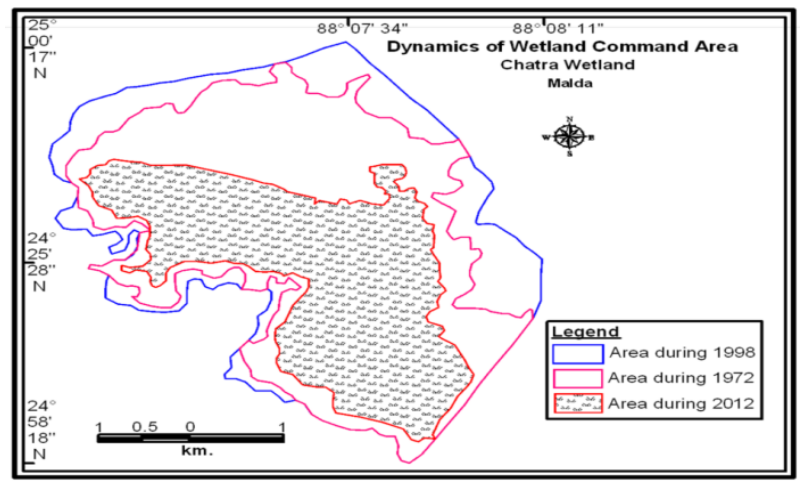

Fig2

(Source: Prepared by the researcher on the basis of Satellite Imagery, Cadastral Map \& Field Survey)

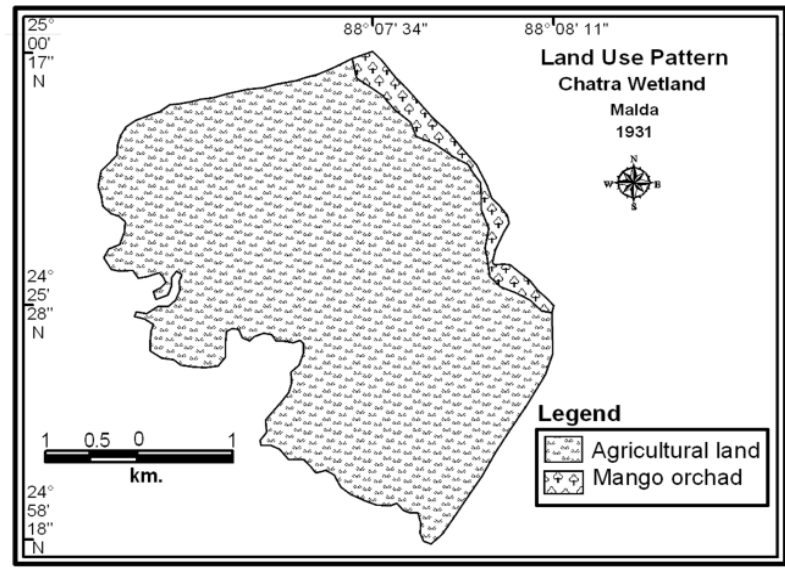

Fig3

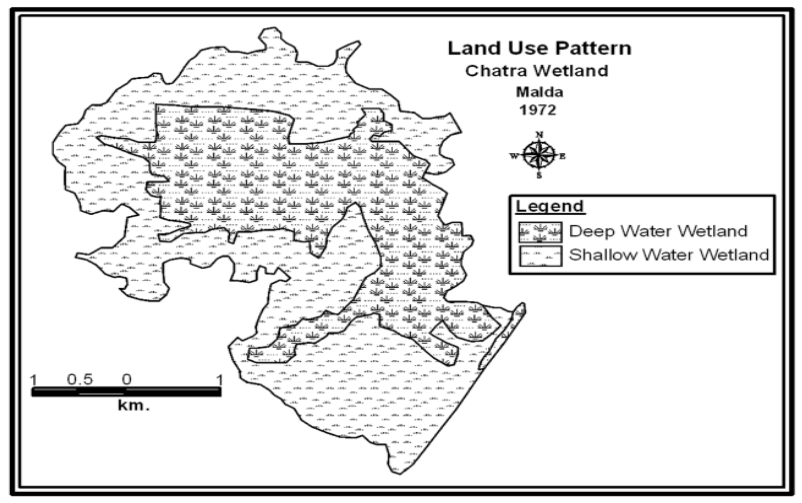

Fig4

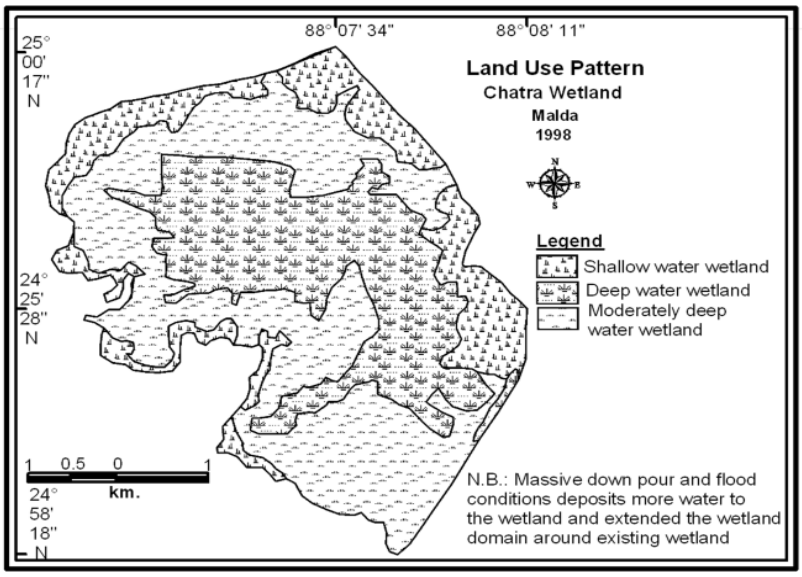

Fig5 


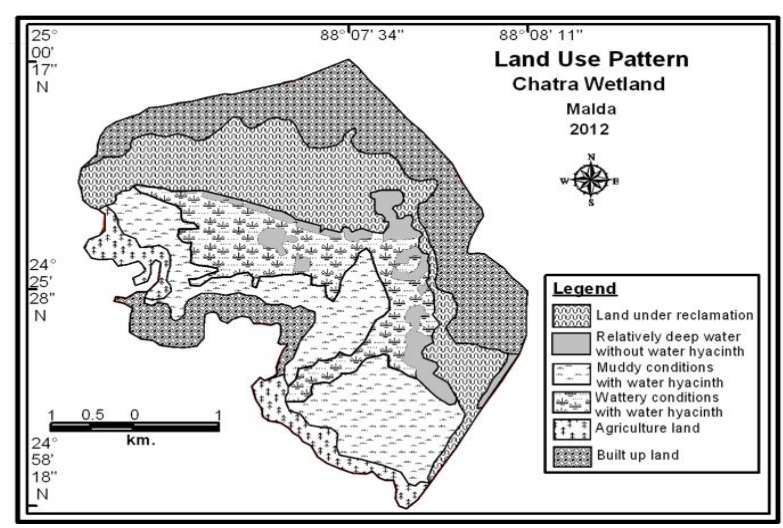

Fig6

(Source: Prepared by the researcher on the basis of Satellite Imagery, Cadastral Map \& Field Survey)

\subsection{Ecological Concerns}

Wetland can produce good economic remuneration and ecological feedback. Chatra wetland can be used for municipal waste management of Malda town, it can help to recharge ground water, can produce huge quantity of fresh fish, crab, and different hydrophytes, subside municipal carbon and other pollutants etc. It should also be mentioned that at present the situation of internal drainage of Malda town is highly vulnerable. So, slightly more monsoon rain in any year may bring urban water stagnation. If wetland is conserved, it could accommodate a substantial volume of water and abate the urban flood possibility. This wetland could be used following the strategies adopted for East Calcutta Wetland.

Any water body possesses biotic entities which are very much part of the ecological character associated with the water body. Since human activities and intervention associated with the beel are obviously of a different nature and degree, the understanding of the ecological status of this water body need identification of biotic diversities other than man. In the following paragraph the aquatic, semi-aquatic and related biotic entities associated with the beel are discussed.

Table1. Biotic Entities of Chatra Wetland

\begin{tabular}{|l|l|l|l|}
\hline Name of the Flora & Scientific Name & Name of the Fauna & Scientific Name \\
\hline Water hyacinth & Eichhornia crassiper & Rui & Lebeo rohita \\
\hline Kulekhara & Hygrophilla & Tengra & Mystus cavasius \\
\hline Thankuni & Centella Asiatic & Punti & Burbus phutunio \\
\hline Hingcha & Enydra fluctuans & Magur & Clarius batrachus \\
\hline Ghima & Polycarpon postratum & Singhi & Heteropneustes \\
\hline Susni sak & Marsilea minuta & Boal & Wallagonia attu \\
\hline Kalmi sak & Ipomoea aquatic & Chang & Ophicephalus gachua \\
\hline
\end{tabular}

(Source: observed primary information)

From human point of view, these common hydrophytes play vital role to support the local people needs e.g. economically (salable product) as well as food value purpose (individual consumptive). Hydrophytes like kulakhara, thankuni, hingcha, gima, kalmi sak are also used for medicinal purpose by the villagers. During the field survey, it has noticed that some people sell Susuni sak, Gima sak, Kalmi Sak, Kulekhara and earn individually Rs. 3500/- in an average per month from local market.

Agricultural residues from the agricultural field of the western portion, liquid urban waste etc. have encouraged luxuriant growth of water hyacinth. It is called eutropication. According to the empirical survey by the researcher, most of the wetland command area is under the grip of unwanted growth of water hyacinth (Fig 7). Some portion where the depth of water is more than $1.5 \mathrm{~m}$., density of these hydrophytes is sparse. Fishermen often clear some portion of wetland providing netting cage and carry on their fish spawning and rearing, catching etc.

It is found that water depth status in different parts of the wetlands is variable In Chatra wetland, depth of water in core areas is more than 2.5 meter and this portion is quite safe from human intervention. But the area under shallow depth is threatened due to dumping of garbage. This process 
is the usual one of wetland reclamation. But as a result ecological hotspot of the wetland and economic returns from it has steadily been declining over the time scale.

Wetland is called ground water recharge machine. As per the definition of wetland, ground water table remains very near to surface or above surface in case of live wetlands. Steady lowering of water table paralyses the water stagnation ability of the wetland. Ground water crisis is one of the principal problems of entire India. In spite of having large number of wetland and rivers, this area is not also free from ground water crisis. In case of Chatra wetland, ground water level is steadily lowering down over time $\left(\mathrm{R}^{2}=0.730\right)$ (Fig 7). Time may come when due to this cause wetland may become fretful. In this condition, the importance of wetland can be felt.

Table2. Ground Water Level Condition of English-Bazer Town

\begin{tabular}{|c|c|c|c|c|c|}
\hline Year & GWL & Year & GWL & Year & GWL \\
\hline 2006 & 6.45 & 2008 & 7.27 & 2010 & 7.8 \\
\hline 2007 & 7.7 & 2009 & 8.13 & 2011 & 8.53 \\
\hline
\end{tabular}

(Source: SWID, Malda)

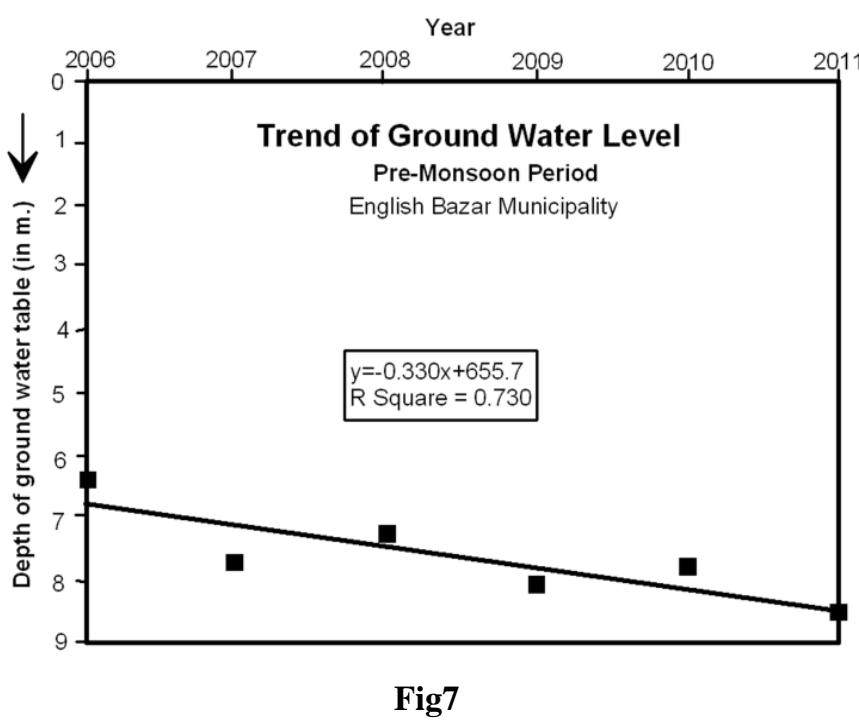

\subsection{Economic Feasibility of the Wetland}

Pisciculture is one of the important aspects of any wetland. This has also been practiced in this Chatra Wetland. But, there is no legal and scheduled possessioner applicable for the fish production of this wetland. The fishing has been controlled from the last ten years by few men, not by any government organization or attempt. Therefore, no authentic calculation of profit or loss is entitled. Yet the primary survey has reported a profit of Rs 2.5 lakh per annum. In some cases, people belonging to the wetland vicinity stealing local oysters/mollusta/barnacles (locally known as 'googli'), tortoises and fishes (table1) for their personal consumption.

Some associated problems for pisciculture of this wetland are

- The sewage of two drains which are located in ward no.3 of the English Bazar municipality is continually filling the Beel, decreases the water quality day by day. As a result, the normal growth of fishes is affected and faced perils.

- The brooding problem of ownership is also prevailed. Hence the fish cultivation here is not in a sound state that must have to be.

On the other, at present a little portion of this wetland being separated by embankment is used as cultivating land for producing Gurgle-nut (makhna) during last few years. This is used for preparation of baby food, sweets, snacks curry etc. It has great demand in European countries, Pakistan, Afghanistan \& Arabian countries etc. By virtue of its dietary properties Makhna is sold at a very high price and thus the future prospect of Makhna cultivation has got very high economic potentiality for the people belonging to the wetland zones. Though Makhna is becoming important 'International Commercial Crop', it has some drawbacks for natural aquatic ecosystem. Because this crop is grown 
only under such ecological condition which has a considerable threat to wetland's natural ecosystem. Plantation of makhna involves the water body to be completely cleared of all weeds etc then insecticides and pesticides are applied to sterilize the water so that insects and fishes cannot eat up the shoots once they come out after germination of seeds. The thick growth of leaves cover water surface all the way. It does not allow sunlight to reach to the surface of water, which is necessary for growth and survival of algae and other weeds. That is why; no fish and other aquatic lives can survive where Makhna has been introduced. So, the element of caution from ecological perspective should be preconditional for such a venture.

\section{CONCLUSiON}

As the Chatra beel is located at the fringe area of English Bazar Municipality, it is bearing the brunt of unchecked urban sprawl though land filling. This is clearly seen in the primary survey and also through comparison of the previous maps with that of the latest one. The people belonging to littoral zones of this wetland seem to be more interested in 'exploiting' the beel land rather than its water content, not to maintain about the ecological components. There are some of the issues that haunt one's mind. Will the beel Chatra survive in future? Will the present anthropogenic onslaught on the system of the beel lead to serious negative consequences? At the same time this beel is no doubt an important item of on which economy of a sizeable population of English Bazar Town leans upon directly or indirectly. The utilitarian aspect from human stand point cannot be ignored too. So it is quite natural that people will try to utilize the beel more and more, thus troding upon the danger zone of 'exploitation'. But from ground water, drainage disposal and ecological perspective piracy of wetland will lead to a great long term hydro-ecological irreversible loss. In order to bridge the gap between ecological set-up and economic prospect for the long term benefit for the people belonging to the vicinity of beel a carefully prepared perspective plain is an immediate necessity. Therefore the author proposes that the municipal authority should immediately take possession of whatever vacant space is left of this beel, stop any further encroachment, landscape it into a park with shrubbery, flowering trees, amusement inputs (childrens' park) and partly de-silting / re-excavating it to give back the water body character. This will indeed provide a breathing space for the urbanites. For implementation of such programme the municipal authority may go for P.P.P. (Public Private Partnership) long term lease or similar administrative approach.

\section{REFERENCES}

[1] Ahamed, S.I., Tiwana, A.S. (2005). Disappearing Wetlands: A Threats to Biodiversity, Geographical Review of India. Vol. 67, No. 1, pp. 96-99.

[2] Bhattacharya, S., K. Mukherjee and J.K. Garg (2000). Wetlands of West Bengal, Institute of Wetland Management and Ecological Design, Calcutta.

[3] Chhattaraj, S. \& Chattaraj, C. (2008). Present Status and Future Strategy to Conserve Wetlands in Malda District, West Bengal. National Geographer, Vol. XLiii, No. 1+2, 243-252.

[4] Kar, S., \& Pal, S. (2012). Ensuing threats on wetland in malda district: A case study on chatra wetland. International Journal of Lakes and Rivers, 5(1), 39-45.

[5] Kar, S.K., \& Molla, H.R. (Winter 2011). Geo-Hydrological Characteristics and Water Quality of selected wetlands of Malda District, West Bengal. Practising Geographer (I.G.F), Vol-15 (number-2): 46-55.

[6] Khatun, J.,A.K.M.A. (2012). Gorgon Cultivation - A serious Threat to Wetland Bio-diversity. Golden Research Thoughts, Vol. 2, Issue- 3, (Sep-2012), pp. 1-9.

[7] Kotze DC and Breen CM (1994). Agricultural land-use impacts on wetland functional values. WRC Report No 501/3/94, Water Research Commission, Pretoria.

[8] Liu. H, Hang, S.Z., Li, Z., Lu, X., Yang, Q (2004). Impacts of Wetlands of Large Scale Land use Changes by Agricultural Development- The Small Sanjang, Ambio A Journal of the Human Environment.

[9] Mitsch, and Gosselink. (2000). Wetlands. John Wiley, New York, USA.

[10] Mitsch, and Gosselink. 1986. Wetlands. Van Nostrand Reinhold, New York.

[11] Mitsch, and Gosselink. 1993. Wetlands. Van Nostrand Reinhold, New York. 2nd Edition. Davis, T., 1994.

[12] Pal, S., \& Akoma, O. C. (2009). Water scarcity in wetland area within Kandi Block of west bengal: A hydro-ecological assessment. Ethiopian Journal of Environmental Studies and Management, 2(3), 1-22.

[13] Pal, S., \& Ziaul, S. (2016). Detection of land use and land cover change and land surface temperature in English Bazar urban centre. The Egyptian Journal of Remote Sensing and Space Sciences, temperature. https://doi.org /10.1016/j.ejrs. 2016.11.003. 
[14] Ramsar Convention Bureau (1997). The Ramsar Convention Manual: A Guide to the Convention on Wetlands (Ramsar, Iran, 1971). 2nd Edition, Ramsar Convention Bureau, Gland, Switzerland.

[15] Ziaul, S., \& Pal, S. (2016). Estimating wetland insecurity index for Chatra wetland adjacent English Bazar Municipality of West Bengal. doi 10.1007/s41324-017-0114-6

\section{AUTHOR'S BIOGRAPHY}

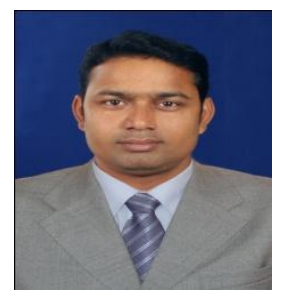

Dr Shyamal Kumar Kar, an assistant teacher in geography of Nayansukh L.N.S.M. high School in West Bengal and has been rendering his service since 2005. He did his Ph D degree on Wetlands of Malda district, West Bengal from Visva Bharati, Santiniketan in 2013. He has been presented some national and international seminars and conferences respectively and also published 10 research papers.

Citation: Dr. Shyamal Kumar Kar. "State of Wetland Transformation and Ecological Concerns - A Case Study of Chatra Wetland, English Bazr, West Bengal”. International Journal of Research in Geography. vol 4, no. 2, 2018, pp. 1-8. doi:http://dx.doi.org/ 10.20431/2454-8685.0402001.

Copyright: (C) 2018 Authors. This is an open-access article distributed under the terms of the Creative Commons Attribution License, which permits unrestricted use, distribution, and reproduction in any medium, provided the original author and source are credited. 